"Mircea cel Batran" Naval Academy Scientific Bulletin, Volume XIX - 2016 - Issue 1

Published by "Mircea cel Batran" Naval Academy Press, Constanta, Romania /I The journal is indexed in:

PROQUEST / DOAJ / DRJI / JOURNAL INDEX / I2OR / SCIENCE LIBRARY INDEX / Google Scholar / Crossref /

Academic Keys / ROAD Open Access / OAJI / Academic Resources / Scientific Indexing Services / SCIPIO

\title{
LABOR RELATIONS OF THE PEASANTS UPON THE CLOSURE OF THE COMMUNITY TYPE ORGANIZATION DURING THE $15^{\text {th }}-16^{\text {th }}$ CENTURIES
}

\author{
Claudiu Mihnea DRUMEA ${ }^{1}$ \\ ${ }^{1}$ Professor of Law, Faculty of Juridical and Economic Sciences, Spiru Haret University
}

\begin{abstract}
The right of displacement and release of neighboring states that during the sixteenth century, the peasants maintain their personal liberty.

Although since the late fifteenth century the tax on cereals called the "bucket out"(1) was introduced, which sought to prevent displacement of peasants, in principle they were free, maintaining their right to resettlement until the reign of Michael the Brave.

The fact that, especially in the second half of the sixteenth century, the congregation, which in the fifteenth century was still quite strong, begins to unravel is attested by the increasing category of the poor within, whose rights over the land are increasingly more spoiled; they even leave the community losing any rights over ancestral land. In legal terms, emerged from the community, they are free men and women, but deprived of their land.

So that, practicing craftsmanship and trade, which lead to establishing themselves in the cities, attract significant changes in peasant life of this period.
\end{abstract}

Keywords: commodity relations, enslavement, redemption, working relations

Romanian peasants' enslavement history is also the history of the decay and the disintegration of the congregation (2). This process consists of a gradual assertion of the individual property and the collapse of the commons, which led to the servitude and ruin of peasants and to the feudal domain formation, the process which contributed to the Romanian feudal society formation. The non-economic enslavement of the congregation during three centuries had different issues: the royal donation rule and the invasion by force of the land, under feudal rulings, without any legislative measures within the reign, enslave the peasant masses. Also, during this period, the enslavement caused by economic reasons took place. Peasants were sold as neighbors (3) and "rumini"(4) because of taxes, famine, invasions, destroying the economic strength of the peasant. In the $15^{\text {th }}$ century and the first half of the sixteenth century, the sales of peasants' "delnita"(5) are relatively few, and entries on the sale of princes (6) and free peasants (7) as neighbors are very rare. This does not mean that at that times, the peasants were subjugated only by force; they were compelled to different economic needs, that forced them to become feudal' neighbors. But form in which it was accomplished was called worship and at first impression it was a voluntary action.

In Romanian countries during the fifteenth and sixteenth centuries there were two basic classes:

- A class made up of people who were plowing the land with the arms and their own means, rendering obligations in nature and labor,
- A class that possessed the land.

In the fifteenth and sixteenth centuries, the village community has passed through different stages in its evolution and suffered different transformations.

First, due to the process of feudalization, the village community becomes subservient.

Secondly, even inside the congregation significant changes occur, which causes stratification of its members and undermines its vitality and strength, leading to disintegration.

Starting with the $14^{\text {th }}$ century, in the Romanian peasant's life occur changes that lead the peasant to important land binding changes, either following the economic coercion, or following the extra economic one.

During this period, the feudal peasants are assigned together with their land parcel upon which they have hereditary rights, keeping intact the freedom of removal, and the peasants' duties were varied:

1. The peasants had to give tithe (8) in animal products, commonly called the Romanian Principality, the customs of sheep and pigs, the cereals' tithe , the wine's tithe, the honey's tithes (9);

2. They were to pay tribute;

3. They had duties of military nature - such as to take part in the battles of the Lord "to make greater army," to work on raising and strengthening of the cities, to ensure "posada" the security of the city and its borders;

4. The peasants had different easements as: the transportation - to bring/ transport the barrels with 


\begin{abstract}
"Mircea cel Batran" Naval Academy Scientific Bulletin, Volume XIX - 2016 - Issue 1
Published by "Mircea cel Batran" Naval Academy Press, Constanta, Romania /I The journal is indexed in: PROQUEST / DOAJ / DRJI / JOURNAL INDEX / I2OR / SCIENCE LIBRARY INDEX / Google Scholar / Crossref /

Academic Keys / ROAD Open Access / OAJI / Academic Resources / Scientific Indexing Services / SCIPIO
\end{abstract}

wine, the hays; the work at the mills, bridges and paths construction, cutting wood and other duties. All these easements within the fifteenth century sources are named work, jobs and duties (10). From the above enumeration of the peasants' duties, one cans see that they consist mainly of tithes and tributes payment of and a series of compulsory jobs which mostly have an agricultural character. Apart from the mentioned servitudes, there are others with an agricultural character and which are the first signs of the compulsory service, called "claca" in the sense of a mandatory farm work for the master. First of all, the peasants were forced to mow the hay, as winter forage necessary for the master's flocks. Since the time of Mircea the Elder, the hay appears in the feudal charters as an obligation (11).

The existence of special officers called the "fânari" - "hay-ers" (12) shows that this sector played an important role in the economy. One might think that in addition to the obligation to hay, there was a hay tithe, as some charters mention both obligations: the tithe of hay and the hay (13).

There is also another indication that leads us to seek the origin of the agricultural compulsory service in the fifteenth century. It is related to the deforestation. Among other duties, the peasants had to cut trees. This task also appears during the reign of Mircea the Elder (14) and was maintained throughout the fifteenth century (15).

In the fifteenth century, the dependent peasant could not be ousted by the master of his ancestral estate, but he had the right to leave it and settle elsewhere - to another master. His duties also included some work/ jobs that had agricultural character of compulsory service that would further develop into the field work to the land owner's advantage.

In the sixteenth century appears the tendency to restrict the rights of peasants over the land and to diminish the resettlement right. Recalling phenomena that arose in the Romanian Principalities' economy during the sixteenth century (16), we should underline that at that time the commodity-money-based economy appeared and developed. This represented a new phase in the development of feudal society in the Romanian Principalities increasing considerably the feudal reserve, which was to bring the master increasingly larger revenues. All of that because of the need to ensure the workforce and to tie the peasant to the land, precluding his/her right to resettlement.

Once the feudal reserve had augmented, the labor force become increasingly popular. On the one hand, it tended to increase the number of dependent peasants, thus stripping the freeholders and the yeomen and turning them into master's peasants, on the other hand, the rush of obtaining the labor force turned the feudal lords into seeking to restrict the right of resettlement of the dependent peasants, and to tie them to the land securing the necessary manpower for field operation.

The process of enslaving peasants took place in the fifteenth century, but still the peasants kept intact their right of resettlement, i.e. in legal terms, they remained free men and women.

But in the late $15^{\text {th }}$ century the measures to restrict the right to resettlement of the peasant are used. So that upon resettlement, the dependent peasants were subject to pay taxes in nature, grains namely, that was called the "bucket". Although the relocation was done without the need of the master's permission, yet it was subject to that tax paid to the land lord.

The right of resettlement, as conditioned upon payment in grain, still was a means of liberation. In the second half of the sixteenth century, the dependent peasants start using other means - the redemption. This transaction is completed between the land lord and the peasant, usually in monetary terms, but occasionally in cattle as well. Along with his/her freedom, the peasant redeemed the "ocina", the land parcel from the community, mentioning often that "delnita" was in her/his possession from "the forefathers - from the state creation" (17) and sometimes even from "the creation of the world" (18).

The action of redemption bore various names: the lording, judging (freeing) or neighboring, as free peasants were called princes, judges or neighbors of the land. In documents relating to the redemption, it is usually showed that the farmers in question were called before "the princes of their land" (19), then the circumstances in which they became neighbors and ultimately the conditions for release from neighboring.

The redemption could be done in different conditions: with or without land, which in the language of the time was called "heads only." When the redemption was made with land, it was stated that the redeemed peasants were to "be princes on their lands again" or "people landholders again."

The landless redemption forced the peasants to leave their ancestral land and leave the village.

Although the servitude process largely penetrated the villages, especially in the second half of the fifteenth century, however, many peasants still kept their freedom. Even the peasants fallen into the dependence upon their masters retained certain ancient rights: such as the hereditary right of towards their land and the right of resettlement. 


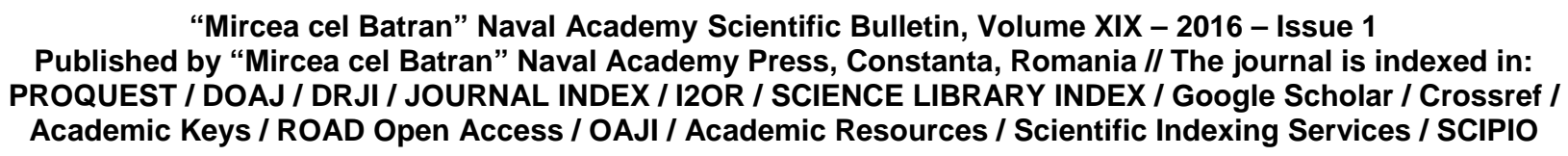

"Mircea cel Batran" Naval Academy Scientific Bulletin, Volume XIX - 2016 - Issue 1 Published by "Mircea cel Batran" Naval Academy Press, Constanta, Romania /I The journal is indexed in: PROQUEST / DOAJ / DRJI / JOURNAL INDEX / I2OR / SCIENCE LIBRARY INDEX / Google Scholar / Crossref / Academic Keys / ROAD Open Access / OAJI / Academic Resources / Scientific Indexing Services / SCIPIO

Along with this category of peasants, called poor who had lost their rights upon the ancestral land, there was the old peasant community category, keeping the hereditary right over the land, even when it was invaded. They were bound to tithe and work. In terms of rights over ancestral land parcel and the freedom of resettlement, in the sixteenth century two categories of peasants were looming:

1. The native peasants of the community, keeping their hereditary right over the land parcel and the right of the resettlement;

2. The poor peasants cut off from the community, who had lost their ancestral right over the parcel land and had been forced to sit on a feudal land upon some informal covenant.

In the sixteenth century, upon the emergence of commodity-money relations, after the grains became commodity, the feudal lords sought to assimilate the covenant peasants to the natives' one, in order to deprive them of their right to resettlement and to tie them to the land.

The history of the sixteenth century peasantry shows us that the enslavement of the peasants had grown increasingly larger, with a pronounced tendency to abolish the right of resettlement of the peasants and to tie them to the land.

The $17^{\text {th }}$ century marks a new period in the history of the peasantry, representing an important step in the process of enslavement by abolishing the right of resettlement and the constant increase of the enslaved peasants' number. The documents relating to the powers of the Polovragi Monastery, in the mid seventeenth century, prove this revealing several times the landless redemption, "The redemption upon heads without land" (20).

\section{BIBLIOGRAPHY:}

[1] (Obsolete) Cereals tax. The complete enslavement occurred very late, because until the eighteenth century the peasants were able to move from one estate to another, paying the "bucket" tax.

[2] The form of social organization specific to the feudal elite, linking this phase to the previous and being characterized by joint work and by combining private and collective property.

[3] Neighbor. In the Middle Ages, he/she was a dependent peasant, forced to work the master's land and to make contributions in cash or in nature; <Lat. vecinus.

[4] Rumân, n. 1. The archaic and popular form for "Romanian;" 2. Subjected to group work, free smallholders that paid tributes and accomplished tasks, people began to be sold (beginning with the $16^{\text {th }}$ century) to Sirs, monasteries or boyars and thus become Rumâni; they could no longer move from the estate where they were and became servants of the owner.

[5] "Delniță, delnițe," n. 1. (In the Middle Ages, Wallachia) Part of the village estate border that was in the possession of a hereditary peasant family living in this village; 2. (In the Middle Ages, Wallachia and Moldavia) A part of a structural subdivision of a village's land. 3. (Obsolete and popular) A long and narrow strip of land lying in a meadow or on a hummock.

[6] During the Middle Ages, in Romanian Principalities, it was a social formation constituted before feudal states through a process of socio-economic and composed of landowners and villagers. In Transylvania they had an important military role in the struggle against the Turks.

[7] "Megieș," n. In the Middle Ages, in Moldavia and Wallachia, it was the term to refer to a free peasant, owner of the land.

[8] "Dijma", the term used for tithe in the Middle Ages in Wallachia, representing one tenth of the main products levied by feudal lords from direct manufacturers.

[9] "Beekeeping" is another term used for taxes during the Middle Ages, representing a tenth part of honey and beeswax products.

[10] "Angara," - a term used in the Middle Ages, in Moldavia and Wallachia, as generic name given to work obligations imposed on the peasantry.

[11] Panaitescu,P. P. 1938. Documentele Tării Românești, I. Documente interne (1369-1490), Bucharest: Fundația „Regele Carol I" Publishing House, p.102, 151, 161, 179

[12] Ibidem, p. 140, 169

[13] Ibidem, p. 199

[14] Ibidem, p.102

[15] Doc. priv. ist. Rom., B. XIII, XIV, XV, p. 192

[16] Iorga, N. 1907. "Evolution de la question rurale en Roumanie," p. 7-13 in A. D. Xenopol, Arhiva, XVIII, p. 233235.

[17] Ghibănescu, Gh. Surete şi Izvoade, XXII, p. 157

[18] Doc. priv. ist. Rom., B. XVII, p. 332-333

[19] "Ocină,", a parcel of land owned with the hereditary right. The term was used in the Middle Ages, in Moldavia and Wallachia.

[20] Ştefulescu, Al. Potavragii, p. 113, 116, 123. 